Syntax Literate : Jurnal Ilmiah Indonesia p-ISSN: 2541-0849

e-ISSN : 2548-1398

Vol. 5, No. 5 Mei 2020

\title{
DAMPAK PANDEMIC DISEASE TERHADAP PERKEMBANGAN PASAR MODAL SYARIAH DI INDONESIA
}

\section{Dini Selasi}

Prodi Hukum Ekonomi Syariah, Sekolah Tinggi Agama Islam Ma'had Ali Cirebon

Email: diniselasi1980@gmail.com

\section{Abstract}

Covid 19 pandemic has plagued almost all countries around the world, many things that have been harmed starting from the political, socio-cultural, religious to the worst are the economic boom. In Indonesia the economy has a huge impact, many industries that 'lay off' their employees, production stops according to government policy but there are some industries that are still allowed to 'work' one of them is the Islamic capital market industry. This study uses a qualitative narrative research method in which primary data comes from various electronic media as well as data from books. With the results of research that the capital market industry is also experiencing tremendous impact, which is certain the stock values down, there are policy changes during the pandemic such as changes in working hours, trading halts, changes in auto rejection but besides that there are still companies that do An IPO or the emergence of a publicly traded company going public on the stock exchange in this pandemic The overall decline in the IHSG uring the pandemic is below $5 \%$.

Keywords: Pandemic, Covid 19, Islamic capital market

\begin{abstract}
Abstrak
Pandemi Covid 19 sudah mewabah hampir negara di seluruh dunia, banyak hal yang dirugikan mulai dari bidang politik, sosial budaya, keagamaan sampai yang paing parah adalah bisang ekonomi. Di Indonesia bidang ekonomi berdampak sangat besar, banyak industri yang 'merumahkan' karyawannya, produksi berhenti sesuai dengan kebijakan pemerintah namun ada beberapa industri yang masih diperbolehkan 'bekerja' salah satunya industri pasar modal syariah. Penelitian ini menggunakan metode penelitian kualitatif naratif dimana data primernya berasal dari berbagai media elektronik juga data yang berasal dari buku-buku. Dengan hasil penelitian bahwa industri pasar modal juga mengalami dampak yang luar biasa, yang pasti nilai-nilai saham turun, adanya perubahan-perubahan kebijakan selama pandemi seperti perubahan jam kerja, melakukan trading halt, perubahan auto rejection tetapi selain hal tersebut masih ada perusahaan yang melakukan IPO atau munculnya perusahaan go public yang melantai di bursa dalam masa pandemi ini. Pernurunan secara keseluruhan nilai IHSG selama pandemi di bawah $5 \%$.
\end{abstract}

Kata kunci: Pandemi, Covid 19, Pasar modal syariah 


\section{Pendahuluan}

Wuhan merupakan tempat pertama kali ditemukan corona virus atau sekarang lebih dikenal dengan COVID 19 yang kemudian menyebar di seluruh dunia dalam waktu 2 bulan waktu pertama kalinya menyebar di Cina dengan menyebabkan berbagai penyakit yang terkadang pasien datang tanpa demam sekalipun (Guan et al., 2020). Penyebarannya sangat cepat dan mematikan sehingga jumlah kasus baru, jumlah meninggal dunia dan jumlah orang yang sembuh dari COVID 19 mengalami kenaikan, saat ini dari data yang ada, COVID 19 telah sangat menghawatirkan perkembangannya dengan 4.215.317 kasus dan 284.674 orang yang meninggal dunia serta 1.506.231 orang yang dinyatakan sembuh dari virus ini (worldometers, 2020) Pandemi ini terjadi juga di Indonesia dengan perkembangan dari data korban meninggal, perkembangan pertumbuhan kasus, pasien yang selamat sebanyak 15.438 kasus COVID 19 di Indonesia, 1.028 orang yang meninggal akibat COVID 19 kemudian korban yang dinyatakan sembuh sebanyak 3.287 orang $(19,2020)$.

Banyak yang dirugikan dengan adanya pandemi ini, yang terasa sangat berdampak adalah kegiatan ekonomi dimana didalamnya ada kegiatan berinvestasi, ada beberapa sektor diantaranya adalah pengaruh pada pasar saham, surat utang dan nilai emas, juga pada perdangangan karena masih megandalkan kegiatan ekspor-impor dari Cina (Abdi, 2020). Sementara itu investasi juga dianjurkan pada ajaran Islam seperti dalam surat yang terdapat dalam Al Qur'an sebagai salah satu landasan dalam berinvestasi yaitu QS. Yusuf (47) bahwa "Supaya kamu bertanam tujuh tahun (lamanya) sebagaimana biasa; maka apa yang kamu tuai hendaklah kamu biarkan dibulirnya kecuali sedikit untuk kamu makan" (Kementrian Agama RI, 2015) bahwa investasi merupakan bentuk dari sebuah ikhtiar untuk mempersiapkan masa depan kita juga dapat membantu pembangunan dan pertumbuhan ekonomi yang menekankan pengembangan sumberdaya manusia serta pemanfaatan alam untuk kesejahteraan dunia akhirat (Muttaqin, 2018).

Pada dasarnya semua kegiatan muamalah itu diperbolehkan kecuali ada aturan yang melarangnya, hal ini berlaku pada kegiatan investasi salah satunya di pasar modal syariah dimana mekanisme bertemunya pihak yang kelebihan dana dan pihak yang kekurangan dana dimana pasar modal tersebut aktivitasnya harus sesuai dengan prinsipprinsip syariah Islam (Abdalloh, 2018). Pasar modal syariah Indonesia sudah menarik perhatian dunia, secara umum pasar modal syariah difasilitasi sukuk, reksadana dan indeks saham syariah (Board, 2015). Dalam pasar modal syariah ada beberapa ketentuan yang harus dihindari yaitu najsy;penawaran palsu, ba'i al-ma'dum;sama dengan short selling, insider trading;informasi dari dalam untuk keuntungan sendiri (DSN-MUI, 2002).

Penelittian ini bertujuan untuk mengetahui dampak pandemi terhadap perkembangan pasar modal syariah Indonesia sehingga kita mengetahui bagaimana dampaknya dan kebijakan apa saja yang diambil oleh pasar modal syariah Indonesia, bagaiman perubahan yang terjadi selama pandemi ini. 


\section{Metode Penelitian}

Penelitian ini menggunakan penelitian kualitatif, menggunakan teknik pengumpulan data seperti observasi, wawancara serta alisis dokumen dengan menggunakan peneliti sebagai instrumen utamanya dan analisis datanya dilakukan setelah pengumpulan data bahkan ketika melakukan pengumpulan data tersebut sehingga dapat menghasilkan penelitian yang menunjukkan kebenaran secara empiris dan logis (Zuchdi Darmiyati Afifah, 2019). Penelitian ini menggunakan data-data yang bersumber dari data kepustakaan baik secara online (e-book, TV news) ataupun sumber data lainnya seperti jurnal, paper report, buku-buku dan lain-lain biasa disebut dengan metode kepustakaan (Zed, 2008)

\section{Hasil dan Pembahasan}

\section{Dampak Pandemic Diasess terhadap Perkembangan Pasar Modal Indonesia}

Dampak COVID 19 sangat berdampak sekali dengan perekonomian di Indonesia, menurut Direktorat Jenderal Pengelolaan Pembiayaan dan Resiko Kemenkeu RI ada beberapa hal yang berimbas pada perekonomian Indonesia seperti kinerja fiskal; ada potensi penurunan penerimaan dari bea masuk dan PNBP SDA, aliran modal; penurunan risk appetite investor mendorong peralihan investasi pada instrumen save haven, self isolation menurunan konsumsi, kinerja ekspor Indonesia; baik barang maupun jasa, kinerja pertumbuhan ekonomi; sektor-sektor terdampak akomodasi, transportasi, retail, manufakur kemudian untuk curent account deficit penurunan kinerja perdagangan barang dan penurunan wisatawan mancanegara berpotensi mendorong peningkatan current account deficit atau CAD (DJPPKemenkeuRI, 2020).

Keadaan ekonomi nasional semakin melemah, secara langsung akan memberikan dampak yang luar biasa bagi masyarakat ketika nilai tukar rupiah melemah mendekati Rp.17.000 per dolar AS yang akan memicu kekhawatiran krisis ekonomi seperti pada tahun 2008 dimana bank dan lembaga keuangan bangkrut, namum tidak dipungkiri pertumbuhan ekonomi nasiona mengalami kontraksi tetapi belum mengalami krisis ekonomi tetapi krisis bidang kesehatan dan kemanusiaan akibat COVID 19 dimana pertumbuhan ekonomi di Indonesia diproyeksikan hanya akan mampu tumbuh 2,5\% hingga 3\% di tahun 2020, saat ini pemerintah sedang berfokus pada penanggulangan pandemi COVID 19 serta pemerintah berusaha agar krisis ekonomi tidak terjadi.(Mulyani, 2020).

Awal tahun 2020 banyak para investor pasar modal Indonesia menaruh harapan besar terhadap perkembangan investasi di pasar modal Indonesia, baik pasar modal konvensional maupun pasar modal syariah, khususnya untuk pergerakan atau perkembangan efek yang ada di bursa yaitu indeks harga saham gabungan (IHSG). Ada beberapa peristiwa dan kebijakan yang dilakukan oleh bursa efek Indonesia sejak awal tahun 2020 ; Januari sampai dengan maret 2020 (berita/siaran-pers idx, 2020) adalah sebagai berikut :

1. Tetap melakukan pencatatan anggota bursa baru yang melantai di pasar modal; PT Tourindo Guide Indonesia Tbk dengan kode saham PGJO yang masuk ke dalam 
sektor Trade, Services \& Investment serta masuk ke Subsektor Tourism, Restaurant; PT Lancartama Sejati Tbk ini dicatatkan dengan kode saham TAMA bidang usaha utama Jasa Konstruksi dan Penyewaan Ruang Kantor dan Hunian; PT Diamond Food Indonesia TBK dengan kode saham DMND bergerak pada sektor Consumer Goods Industry dengan subsektor Food and Beverages; PT Esta Multi Usaha Tbk. (ESTA) dan PT Batulicin Nusantara Maritim Tbk.

2. Penguatan IHSG (Indeks Harga Saham Gabungan) masih meguat pada bulan Januari 2020 sampai dengan Februari 2020 tetapi terjadi perubahan,IHSGulai melemah seiring semakin kuatnya kejadian pandemi COVID 19 di Indonesia. berikut keadaan di bursa efek Indonesia.

a. 17 Januari 2020; Data perdagangan selama sepekan ditutup dengan positif dilihat dari pergerakan Indeks Harga Saham Gabungan (IHSG) yang mengalami penguatan sebesar 0,27 persen menjadi 6.291,657 dari 6.274,941 pada penutupan perdagangan pekan sebelumnya. Kemudian, nilai kapitalisasi pasar selama sepekan juga mengalami kenaikan sebesar 0,32 persen menjadi Rp7.262,002 triliun dari Rp7.238,817 triliun pada penutupan perdagangan minggu lalu.

b. 7 Februari 2020; Mengawali pekan pertama di bulan Februari 2020 data perdagangan PT Bursa Efek Indonesia (BEI) ditutup positif, hal tersebut ditandai dengan bangkitnya Indeks Harga Saham Gabungan (IHSG) pada pekan ini yang mengalami peningkatan sebesar 1,00 persen menjadi 5.999,607 dari 5.940,048 pada penutupan perdagangan pekan lalu.

c. 21 Februari 2020; Data perdagangan PT Bursa Efek Indonesia (BEI) pada pekan ini ditutup positif, hal tersebut berdampak pada meningkatnya Indeks Harga Saham Gabungan (IHSG) sebesar 0,26 persen menjadi 5.882,255 dari 5.866,945 pada penutupan perdagangan pekan lalu. Senada dengan IHSG, nilai kapitalisasi pasar selama sepekan juga mengalami peningkatan sebesar 0,28 persen menjadi Rp6.800,649 triliun dari Rp6.781,861 triliun pada penutupan perdagangan pekan lalu.

d. 28 Februari 2020; Data perdagangan selama sepekan ini ditutup bervariasi dengan rata-rata nilai transaksi harian yang mengalami peningkatan tajam sebesar 15,60 persen atau sebesar Rp7,068 triliun dari Rp6,114 triliun pada pekan sebelumnya. Kemudian, peningkatan juga terjadi pada rata-rata volume transaksi harian, yaitu sebesar 9,91 persen atau sebesar 6.860 miliar unit saham dari 6.241.

e. 2 Maret 2020; Mengakhiri perdagangan bulan Februari 2020, sejak awal tahun Indeks Harga Saham Gabungan (IHSG) telah turun sebanyak minus 13,44\% atau 5.452,704. Penurunan ini juga dialami oleh seluruh bursa utama dunia (memiliki kapitalisasi pasar lebih dari atau sama dengan 100 miliar USD), termasuk bursabursa di ASEAN. Adapun penurunan tertinggi dialami Thailand dan diikuti Indonesia, Filipina, Vietnam, Malaysia, dan Singapura dengan penurunan 
sebesar $-15.03 \%,-13.44 \%,-13.15 \%,-8.2 \%,-6.68 \%$, dan miliar unit saham pada penutupan minggu lalu.

f. 6 Maret 2020; Data perdagangan PT Bursa Efek Indonesia (BEI) pada pekan pertama bulan Maret ditutup positif dibandingkan pekan lalu, hal tersebut terlihat dari Indeks Harga Saham Gabungan (IHSG) dan nilai kapitalisasi pasar yang keduanya ditutup dengan mengalami peningkatan sebesar 0,84 persen. Untuk IHSG meningkat menjadi 5.498,540 dari 5.452,704 dan untuk nilai kapitalisasi pasar berada pada posisi Rp6.356,910 triliun dari Rp6.304,025 trilun pada perdagangan pekan lalu.

g. 21 Maret 2020; Data rata-rata nilai transaksi harian dan rata-rata volume transaksi harian PT Bursa Efek Indonesia (BEI) selama sepekan ditutup dengan menunjukkan peningkatan. Untuk rata-rata nilai transaksi harian mengalami peningkatan sebesar 2,12 persen menjadi Rp7.987 triliun dari Rp7.821 triliun pada pekan sebelumnya. Kemudian, rata-rata volume transaksi harian menunjukkan peningkatan sebesar 15,35 persen menjadi 7.302 miliar unit saham dari 6.330 miliar unit saham pada pekan sebelumnya

3. Melakukan Auto Rejection

a. Menindaklanjuti Surat Perintah Kepala Departemen Pengawasan Pasar Modal 2A Otoritas Jasa Keuangan Nomor: S-273/PM.21/2020 tanggal 9 Maret 2020 perihal Perintah Mengubah Batasan Auto Rejection pada Peraturan Perdagangan di Bursa Efek dan Surat Keputusan Direksi PT Bursa Efek Indonesia Nomor: Kep-00023/BEI/03-2020 perihal Perubahan Batasan Auto Rejection Juga berdasarkan Keputusan Direksi PT Bursa Efek Indonesia Nomor: Kep00025/BEI/03-2020 perihal Perubahan Peraturan Nomor II-A tentang Perdagangan Efek Bersifat Ekuitas, perlu disampaikan bahwa kebijakan perubahan batasan Auto Rejection tersebut dilakukan untuk mengurangi tekanan terhadap pasar modal Indonesia dan mencegah terjadinya penurunan Indeks Harga Saham Gabungan (IHSG) lebih lanjut.

b. Merupakan penolakan secara otomatis oleh JATS terhadap permintaan beli efek bersifat ekuitas yang dimasukkan ke JATS akibat dilampauinya batasan harga atau jumlah efek bersifat ekuitas yang ditetapkan oleh bursa, sementara JATS (Jakarta Automated Trading System) adalah sistem perdagangan efek yang berlaku di bursa (IDX Islamic, 2020a)

4. Menerapkan ketentuan Trading Halt (pembekuan sementara perdaganagn) atas perdagangan di bursa efek Indonesia.

a. Menindaklanjuti Surat Perintah Kepala Departemen Pengawasan Pasar Modal 2A Otoritas Jasa Keuangan Nomor: S-274/PM.21/2020 tanggal 10 Maret 2020 perihal Perintah Melakukan Trading Halt Perdagangan di Bursa Efek Indonesia Dalam Kondisi Pasar Modal Mengalami Tekanan dan Surat Keputusan Direksi PT Bursa Efek Indonesia Nomor: Kep-00024/BEI/03-2020 tanggal 10 Maret 2020 perihal Perubahan Panduan Penanganan Kelangsungan Perdagangan di Bursa Efek Indonesia. 
b. Trading halt adalah pembekuan sementara perdagangan dengan kondisi seluruh pesanan yang belum teralokasi akan tetap dalam JATS (Jakarta Automated Trading System) dan dapat ditarik oleh anggota bursa, ada beberapa tindakan yang dilakukan bursa jika terjadi penurunan yang sangat tajam dalam saru hari; IHSG mengalami penurunan lebih dari 5\% ; akan dilakukan trading halt selama 30 menit; IHSG mengalami penurunan lanjutan hingga lebih dari $10 \%$ akan dilakukan trading halt selama 30 menit; IHSG mengalami penurunan lanjutan hingga lebih dari 15\%; akan dilakukan trading suspend (IDX Islamic, 2020b).

c. Trading halt dilakukan pada :

1) Kamis, 12 Maret 2020 telah terjadi pembekuan sementara perdagangan (trading halt) pada sistem perdagangan di Bursa Efek Indonesia pada pukul 15.33 waktu JATS yang dipicu penurunan Indeks Harga Saham Gabungan atau IHSG mencapai 5,01 persen.

2) Jumat, 13 Maret 2020 telah terjadi pembekuan sementara perdagangan (trading halt) pada sistem perdagangan di Bursa Efek Indonesia pada pukul 09:15:33 waktu JATS yang dipicu penurunan Indeks Harga Saham Gabungan atau IHSG mencapai 5 persen.

3) Selasa, 17 Maret 2020 telah terjadi pembekuan sementara perdagangan (trading halt) pada sistem perdagangan di Bursa Efek Indonesia.

4) Kamis, 19 Maret 2020 telah terjadi pembekuan sementara perdagangan (trading halt) pada sistem perdagangan di Bursa Efek Indonesia pada pukul 09:37:18 waktu JATS yang dipicu penurunan Indeks Harga Saham Gabungan atau IHSG mencapai 5 persen.

5) Senin, 23 Maret 2020 telah terjadi pembekuan sementara perdagangan (trading halt) pada sistem perdagangan di Bursa Efek Indonesia pada pukul 14:52:09 waktu JATS yang dipicu penurunan Indeks Harga Saham Gabungan atau IHSG mencapai 5 persen.

5. Perubahan jam perdagangan pada Bursa Efek Indonesia (IDX, 2020)

Tabel 1 Perubahan Jam Perdagangan Bursa Efek Indonesia

\begin{tabular}{lccc}
\hline Pasar & Sesi & $\begin{array}{c}\text { Sebelumnya } \\
\text { (Senin-Kamis) }\end{array}$ & $\begin{array}{c}\text { Menjadi } \\
\text { (Senin-Jumat) }\end{array}$ \\
\hline & Pra Pembukaan & $08.45 .00-08.55 .00$ & tetap \\
\cline { 2 - 4 } & $\begin{array}{c}\text { Pembentukan } \\
\text { Harga Pembukaan }\end{array}$ & $08.55 .01-08.59 .59$ & tetap \\
\cline { 2 - 4 } & Sesi 1 & $09.00 .00-12.00 .00$ & $09.00 .00-11.30 .00$ \\
\cline { 2 - 4 } & Sesi 2 & $11.30 .00-15.49 .59$ & $13.30 .00-14.49 .59$ \\
\cline { 2 - 4 } Reguler & Pra Penutupan & $15.50 .00-16.00 .00$ & $14.50 .00-15.00 .00$ \\
\cline { 2 - 4 } & Pembentukan & $16.00 .01-16.04 .59$ & $15.00 .01-15.04 .59$ \\
\hline Tunai & Harga Penutupan & & \\
\hline Negoisasi & Pasca Penutupan & $16.05 .00-16.15 .00$ & $15.05 .00-15.15 .00$ \\
\hline & Sesi 1 & $09.00 .00-12.00 .00$ & $09.00 .00-11.30 .00$ \\
\hline
\end{tabular}


Jika dilihat dari penurunan Indeks Harga Saham Gabungan atau IHSG pada pasar modal syariah Indonesia yang berdampak pada penurunan secara umum pada harga saham khususnya dan pada efek syariah yang lainnya seperti sukuk, reksadana dan lain-lain sangat menghawatirkan dari sisi para investor tetapi hal tersebut bisa dilihat dari berbagai sisi bagi investor, tergantung tipe investor itu sendiri, seperti analisis sederhana dibawah ini ;

a. Akan menciptakan persepsi berbeda dari pasar; perekonomian dunia melambat yang mengakibatkan persepsi return yang menurun, tidak akan sebagus tahun sebelumnya sehingga banyak investor yang menjual sahamnya dan masyarakat saat ini lebih senang memiliki uang tunai dibanding dengan bentuk investasi (emas, saham).

b. Ketika IHSG turun, jika investor day trading (beli saham pagi kemudian jual sore harinya) disarankan tidak masuk dalam trading tersebut karena semua perusahaan di luar analisis fundamental perusahaan. Jika investor untuk investasi jangka panjang; perhatikan price earning ratio atau PER, dept to equitty ratio atau DER, fundamental bagus, harga murah disarankan untuk membeli karena kesempatan keadaan market akan naik kembali setelah pandemi ini selesai.

c. Jika harga saham turun ; tergantung pada keyakinan investor jika menjadi investor untuk jangka panjang maka disarankan untuk membeli tetapi jika tidak yakin akan adanya perubahan keadaan maka sebaiknya cutloss atau menjual saham yang dimiliki.

\section{Kesimpulan}

Dalam keadaan darurat atau lebih tepatnya pandemi yang terjadi saat ini akibat adanya COVID 19 yang hampir mempengaruhi seluruh kegiatan masyarakat dunia baik keadaan politik, sosial, budaya dan ekonomi. Salah satu penggerak ekonomi nasional adalah pasar modal syariah yang mengalami goncangan atau pengaruh adanya pandemi ini sehingga semua kegiatan di pasar modal syariah berubah baik dari kebijakan atau ketentuan seperti pasar modal syariah melakukan trading halt, adanya perubahan jam perdagangan bursa, adanya perubahan pada sistem auto rejection, terjadi penurunan atau nilai IHSG melemah dalam beberapa waktu yaitu di bawah 5\% akan tetapi masih ada beberapa perusahaan go public baru yang melantai di bursa. 


\section{BIBLIOGRAFI}

19, Gugus Tugas Percepatan Penanganan Covid. (2020). Infografis COVID-19 (13 Mei 2020). Retrieved from https://covid19.go.id/p/berita/infografis-covid-19-13-mei2020

Abdalloh, Irwan. (2018). Pasar Modal Syariah. Jakarta: PT Elex Komputindo.

Abdi, Muhammad Nur. (2020). Krisis Ekonomi Global Dari Dampak Penyebaran Virus Corona (Covid-19). AkMen Jurnal Ilmiah, 17(1), 90-98. https://doi.org/10.37476/akmen.v17i1.866

berita/siaran-pers idx. (2020). Siaran Pers Pasar Modal Indonesia. Retrieved March 25, 2020, from idx.co.id website: https://www.idx.co.id/berita/siaran-pers/

Board, Islamic Financial Services. (2015). Islamic financial services industry stability report. Islamic Financial Services Board.

DJPP Kemenkeu RI. (2020). Kenali Risiko Ekonomi Akibat Covid 19. Retrieved March 24, 2020, from Instragram DJPPR website: http://www.instagram/djpprkemenkeu

DSN-MUI. (2002). Fatwa Dewan Syari'ah Nasional Nomor 40/DSN-MUI/X/2002 Tentang Pasar Modal dan Pedoman Umum Penerapan Prinsip Syariah di Bidang Pasar Modal. Retrieved October 23, 2019, from dsnmui.or.id website: https://dsnmui.or.id/kategori/fatwa/page/5/

Guan, Wei jie, Ni, Zheng yi, Hu, Yu, Liang, Wen hua, Ou, Chun quan, He, Jian xing, Liu, Lei, Shan, Hong, Lei, Chun liang, \& Hui, David S. C. (2020). Clinical characteristics of coronavirus disease 2019 in China. New England Journal of Medicine, 382(18), 1708-1720. https://doi.org/10.1056/NEJMoa2002032

IDX. (2020). Jam Perdagangan. Retrieved March 27, 2020, from idx.co.id website: https://www.idx.co.id/investor/jam-perdagangan/

IDX Islamic. (2020a). Auto Rejection. Retrieved March 25, 2020, from IDX Islamic website: www.idx.co.id/peraturan/keputusan-direksi

IDX Islamic. (2020b). Trading Halt. Retrieved March 26, 2020, from IDX Islamic website: https://www.idx.co.id/peraturan/keputusan-direksi/

Kementrian Agama RI. (2015). Al-Qur'an dan Terjemahannya. Semarang: PT.Kumudasmoro Grafindo.

Mulyani, Sri. (2020, March 25). Apakah Indonesia sedang alami krisis? Ini jawaban Sri Mulyani. Kontan.Co.Id. Retrieved from https://nasional.kontan.co.id/news/apakahindonesia-sedang-alami-krisis-ini-jawaban-sri-mulyani

Muttaqin, Rizal. (2018). Pertumbuhan Ekonomi dalam Perspektif Islam. Maro, 1(2), 
Dini Selasi

117-122. https://doi.org/10.31949/mr.v1i2.1134

worldometers. (2020). Coronavirus. Retrieved May 11, 2020, from worldometer.info website: https://www.worldometers.info/coronavirus/

Zed, Mustika. (2008). Metode Penelitian Kepustakaan. Jakarta: Yayasan Obor Indonesia.

Zuchdi Darmiyati Afifah, Wiwiek. (2019). Analisis Konten Etnografi, Grounded Theory, Hermeneutika dalam Penelitian. Jakarta: Bumi Aksara. 